\title{
Preliminary Study of Ozonated Water to Preserve the Quality of Tofu: The Effect of Exposure Time and Replacement of Ozonated Water
}

\author{
Eva Fathul Karamaha, ${ }^{\mathrm{a},}$ Muhammad Zaki Zahirsyah ${ }^{\mathrm{a}}$, Rana Rezeki Najeges ${ }^{\mathrm{a}}$ \\ ${ }^{a}$ Department of Chemical Engineering, Faculty of Engineering, Universitas Indonesia, Depok 16424, Indonesia \\ Corresponding author: "eva.fathul@ui.ac.id
}

\begin{abstract}
Tofu is a very popular source of vegetable protein in Indonesia. However, tofu is a very perishable food type because its water content is also very high and high in protein. Ozonated water is one of many solutions to preserve the quality of tofu. Ozone is an anti-microbial agent and is already recognized as safe to be contacted with food. This research aims to see the effect of exposure time and replacement of ozonated water in preserving tofu's quality. The quality parameters that are observed in this research are total mesophilic aerobic bacteria (TMAB), $\mathrm{pH}$, and protein level. The tofu is exposed to ozonated water $\left(0.32 \mathrm{mg} \mathrm{O}_{3} / \mathrm{L}\right)$ for 40,80 , and 120 minutes. For water replacement, tofu is exposed to ozonated water $\left(0.32 \mathrm{mg} \mathrm{O}_{3} / \mathrm{L}\right)$ for 120 minutes, and the water replacement occurred every 40 and 60 minutes (unreplaced water is observed as well). One hundred twenty minutes exposure can disinfect $51 \%$ TMAB and suppress the rate of change in $\mathrm{pH}$ and protein level in tofu. Moreover, water replacement every 40 minutes can disinfect $96 \% \mathrm{TMAB}$ and suppress the rate of change of $\mathrm{pH}$ and protein level. This research shows that replacing ozonated water every 40 minutes is the most effective treatment among others in preserving the quality of tofu.
\end{abstract}

Keywords - Food quality; mesophyll-aerobic bacteria; ozonated water; ozone; tofu.

\section{INTRODUCTION}

The development of food safety technology always continues to be studied. However, there are still many problems found in it, especially in maintaining these foods' quality. Many foods are not suitable for consumption due to damage to these foods' quality, such as the emergence of rancidity due to microbiological contamination. One example of foods that contain many microbiological contaminants is foods with high water content, such as tofu. Therefore, microbial activity becomes an important parameter in the shelf life of food.

Food can become toxic because it has been contaminated by pathogenic bacteria, which can then grow and multiply during storage. The bacterial group that is often found in food is the aerobic mesophilic bacteria, which are bacteria that live optimally at a temperature of $25^{\circ}-37^{\circ} \mathrm{C}$ and perform aerobic respiration. Aerobic mesophyll bacteria are considered microbial indicators in assessing the level of sanitation. Foods contaminated with aerobic mesophyll bacteria can cause diseases of the human digestive tract, such as diarrhea. Microbial activity in food products can degrade nutrients in these foods so that the quality will be reduced.
Therefore, the presence of these bacteria in a food product must be destroyed.

To maintain the quality of food, many preservation techniques have been done. One of them is the technique of salting, freezing, canning, and drying. Besides, many foods are preserved by adding chemical preservatives. For foods with high water content, such as tofu, one commonly used preservative is sodium benzoate. Sodium benzoate can be used because it can deactivate pathogenic bacteria. However, many people still do not understand the difference between food and non-food preservatives. The use of non-food preservatives such as formalin is still widely used since 2005 until now [1].

Ozone is an alternative solution to maintaining the quality of food. Many people began to look at ozone technology as a microorganism disinfection agent that can meet industry expectations according to government regulations and consumers' acceptability [2]. Ozone has also been recognized as safe to be used in the food industry. In 2001, ozone-containing media was approved by the FDA (Food and Drug Administration) in direct contact with food products such as poultry, meat, fish, dairy and milk and vegetables and fruit [3]-[7]. 
Research on the utilization of ozone in maintaining the quality of food has been done previously. Many of them devoted to ozone in the form of gases and spraying of an aqueous solution. Ozone gas with a certain dose can kill Listeria in salmon [8]-[11]. The study also showed the effect of ozone doses in deactivating bacteria. However, the use of ozone gas with high doses can have a negative impact on human health. Exposure to ozone at $0.1-1.0 \mathrm{ppm}$ can cause dry throat, irritation to the respiratory system, headaches and smarting eyes [12]. Therefore, the use of ozonated water can be a suitable method in overcoming it. Ozonated water with a certain dose can be used as a storage medium, but not for a long time. This is because ozone in water can quickly decompose back into oxygen $\left(\mathrm{O}_{2}\right)$.

Therefore, a solution is needed to maintain the effectiveness of water when used as a storage medium. Several research report that gaseous ozone had a weaker activity than ozonated water. When ozone is applied as a gas, the necessary exposure time must be longer, or the concentration used must be higher than for the application of ozonized water [13]. Very view study has been done on ozonated water applications for tofu [14]. However, the study has not investigated the effect of replacement of ozonated water within a certain time period. This study utilizes ozonated water to see the effectiveness of ozone in suppressing the change rate of tofu's quality. The evaluated parameters are total mesophyll-aerobic bacteria (TMAB), $\mathrm{pH}$, and protein content. The independent variables in this experiment are the exposure time between the ozonated water and tofu as well as the replacement period of the ozonated water.

\section{MAterials AND MeTHOD}

\section{A. Preparation of Samples}

Tofu was obtained from tofu factory in Lenteng Agung (Depok, West Java, Indonesia). They were rinsed with water before any further usage to clean any unnecessary contaminant. Then, they were cut into pieces with the same mass (50gr) before being used in the treatment and divided into 2 batches. Each batch represents different variation -1 batch for variation of exposure time, and the other is for variation of the water-replacement period. To characterize the tofu, physical (pH and protein content) and microbiological (TMAB) measurements were performed. After characterization, all tofu's in the same batch are divided into different boxes for exposure with ozonated water.

\section{B. Ozone Treatment}

The treatment of ozonated water to tofu was conducted in two variations, the variation of exposure time and the

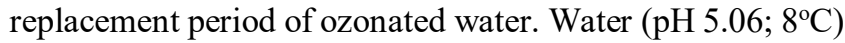
is exposed to ozone gas with the system in Figure 1. In determining the variation in exposure time, various preliminary studies were conducted. The decomposition profile of ozone in water were observed by testing ozone solubility in water every 10 minutes during 180 minutes of storage in $8^{\circ} \mathrm{C}$. Tofu, on variations of exposure time, is exposed to ozonated water for different durations $-40,80$, and 120 minutes. While on the water replacement period variation, the contact duration between tofu and water is 120 minutes.

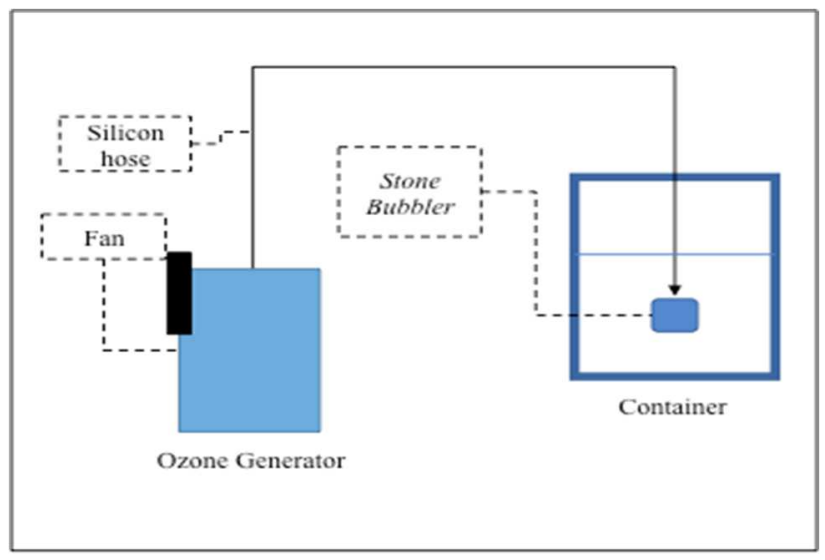

Fig. 1 Ozone Contact System

During this duration, ozonated water are replaced within 3 different periods - every 40 minutes, 60 minutes, and without replacement. Control tofu (non-ozonated tofu) is also observed in this study as a comparison. The quality that is observed in this study is seen from the microbial quality and physical quality. The observation of physical qualities is the change of $\mathrm{pH}$ and protein content in tofu. As for microbiological quality, the parameter observed is the change of TMAB. The samples were stored for 7 days in $8^{\circ} \mathrm{C}$ and were analyzed every 2 days (days 1, 3, 5, and 7).

\section{Microbiological Analysis}

Microbial analyses were performed to determine the number of bacteria contained in the tofu. The bacteria that were observed is TMAB. The analysis was performed according to SNI 19-2897-1992 point 2. The quantification of TMAB was done through 2 stages: the making of bacterial suspension and the quantification itself. The process of making bacterial suspension was done by shaking 1 gram of tofu and 99 sterile water with shaker for 30 minutes (200 rpm). Furthermore, the suspension was then being used to quantify the bacteria by using PCA (Plate Count Agar) medium. All the results are expressed as cfu/gr.

\section{Physical Analysis}

Physical analysis was carried out before and after the tofu is treated with ozone. The $\mathrm{pH}$ test aims to determine the degree of acidity contained in tofu. The reference $\mathrm{pH}$ testing procedure is from SNI-01-2891-1992 point 16. Before the test, $\mathrm{pH}$ meters were calibrated with buffer solution $(\mathrm{pH} 4$ and $\mathrm{pH} 7$ ). 3 gr tofu is first dissolved with $15 \mathrm{ml}$ distilled water, then was homogenized with a magnetic stirrer. Then, the solution is used to measure the $\mathrm{pH}$. Lastly, the protein content of tofu was determined with the Kjeldahl method according to SNI 01-2891-1992 point 7.1.

\section{RESULT AND DISCUSSION}

\section{A. The Effect of Exposure Time}

Tofus were exposed to ozonated water $(0.32 \mathrm{mg} / \mathrm{L})$ for 40 , 80 , and 120 minutes under cold temperature $\left(8^{\circ} \mathrm{C}\right)$.

1) The Change of TMAB: The initial amount of TMAB before exposed to ozonated water is $180,000 \mathrm{cfu} / \mathrm{gr}$ or 5.25 
$\log \mathrm{cfu} / \mathrm{gr}$. After contact, the number of TMAB at different exposure times can be seen in Figure 2.

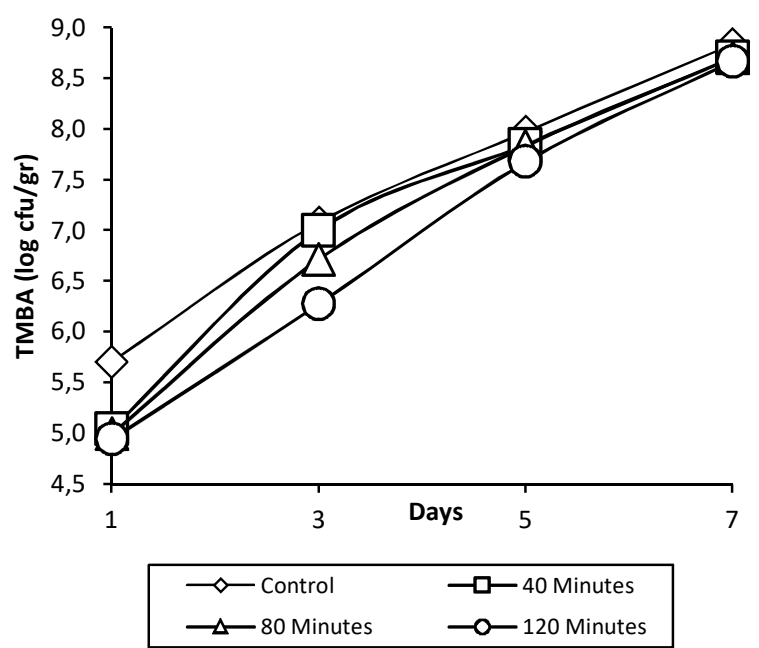

Fig. 2 TMAB in different exposure time (ozone dosage: $0.32 \mathrm{mg} / \mathrm{L}$; storage temperature: $8^{\circ} \mathrm{C}$; water $\mathrm{pH}: 5$ )

Based on Figure 2, the number of TMAB in the tofu that were exposed with the ozonated water was lower than that which was not exposed. This shows that ozone is able to disinfect the aerobic mesophyll bacteria present in the tofu. The results also show that the longer the duration of contact, the less TMAB contained in the tofu. On the 1st day, the smallest number of TMAB was found in the tofu with a contact duration of 120 minutes, which was $4.94 \mathrm{log} \mathrm{cfu} / \mathrm{gr}$. The number of TMAB in the duration of 80 minutes is also less than at 40 minutes. The same pattern was also observed on the $3^{\text {rd }}, 5^{\text {th }}$, and $7^{\text {th }}$ days of storage, wherein those days the least number of TMAB was found in the tofu with a contact duration of 120 mins. This is due to the reduced number of TMAB right after the tofu was exposed to ozonated water. At a duration of 120 minutes, ozone is able to disinfect more bacteria than the duration of 80 and 40 minutes.

However, the results show that there are no significant differences at different contact times. This is due to the reduced amount of dissolved ozone at longer contact times. Over time, ozone dissolved in water will decompose. The amount of dissolved ozone after 120 minutes is less than 80 and 40 minutes. Therefore, although the number of TBMA at 120 minutes contact time was the least, the difference was not too significant compared to 80 - and 40 -minutes contact time.

The effect of exposure time on the amount of TMAB can also be seen on the percentage of bacteria disinfected by ozone. Figure 3 shows the percentage of bacteria disinfected at each exposure time. It was calculated through equation 1.

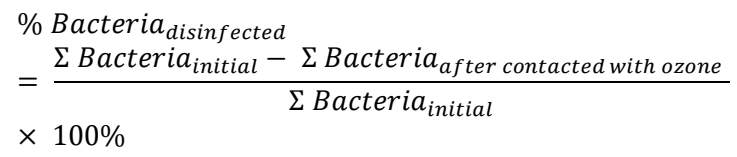

The results showed that the tofu with 120 mins exposure time had the highest number of disinfected bacteria -4.96 $\log \mathrm{cfu} / \mathrm{gr}$ with a disinfection percentage of $51 \%$. The longer the exposure time between the tofu and the water, the more TMAB were disinfected. This is because the longer exposure time provide more opportunity for ozone to infect more bacteria.

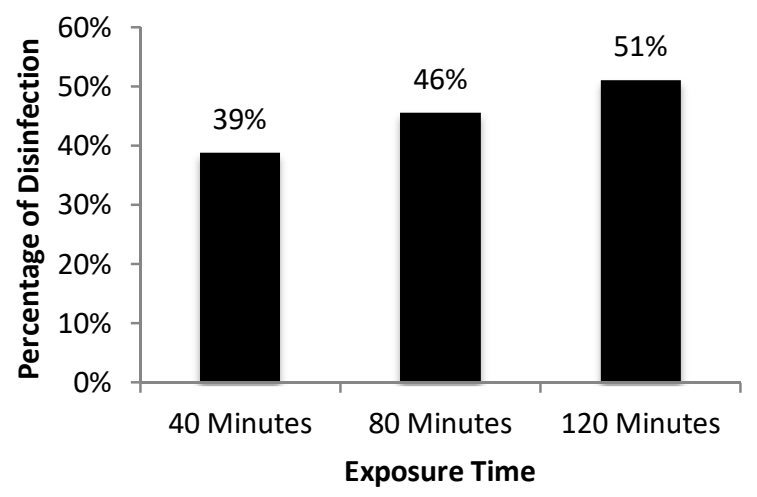

Fig. 3 Percentage of Disinfection in Different Exposure Time (ozone dosage: $0.32 \mathrm{mg} / \mathrm{L}$; storage temperature: $8^{\circ} \mathrm{C}$; water $\mathrm{pH}: 5$ )

The highly reactivity of ozone makes it able to disinfect contaminants on the medium that it contacts, including microorganisms. Deactivation of bacteria by ozone involves the reaction between ozone with cell membranes and also components that are in the cell cytoplasm (organelles, enzymes, nucleic acids, etc.). Ozone oxidizes sulfhydryl groups in bacterial cells and breaks down enzymes and other proteins into smaller peptides [15].

2) The Change of $p H$ : The effect of exposure time on the $\mathrm{pH}$ of tofu can be seen in Figure 4. The result shows that the longer the exposure time, the slower the change of the $\mathrm{pH}$. It has a correlation with the amount of TMAB that grows during storage. The slow rate of $\mathrm{pH}$ change at longer exposure time is due to the smaller number of bacteria in the tofu. It can be observed that the least $\mathrm{pH}$ change existed in the sample with 120 minutes exposure time.

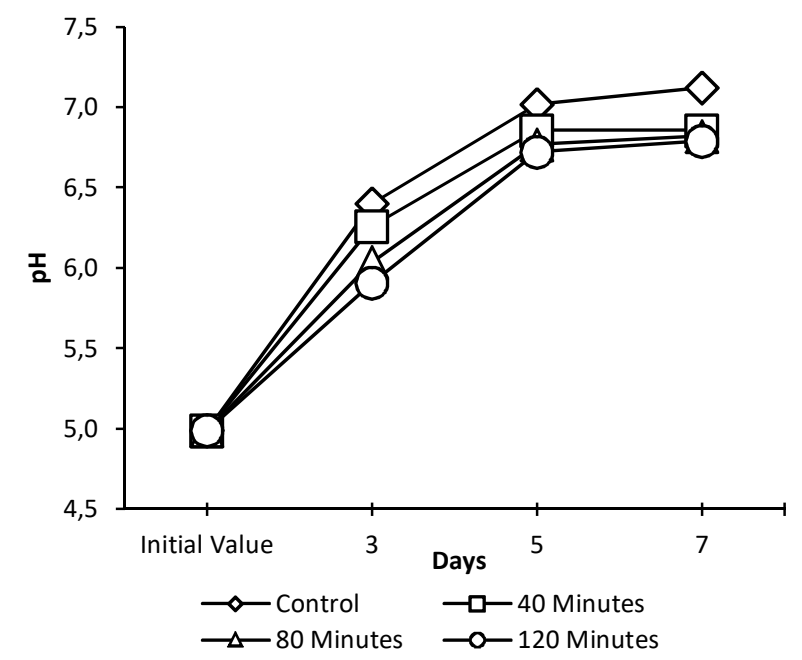

Fig. $4 \mathrm{pH}$ Value in Different Exposure Time (ozone dosage: $0.32 \mathrm{mg} / \mathrm{L}$; storage temperature: $8^{\circ} \mathrm{C}$; water $\mathrm{pH}: 5$ )

However, the $\mathrm{pH}$ value at different contact times does not have such a significant difference. This has the same pattern as the number of TBMA. Because the difference in the number of TBMA in each variation of contact time is not so significant, the $\mathrm{pH}$ value is also not too different. The difference in $\mathrm{pH}$ that is not too significant is still categorized 
as accurate, because the difference in $\mathrm{pH}$ values in all samples is above the error margin of the $\mathrm{pH}$ meter, which is $\pm 0.02 \mathrm{pH}$ units.

During storage, it can be observed that the $\mathrm{pH}$ value for all treatments is increasing. This is caused by the compounds from protein degradation by bacteria. The growing number of bacteria will speed up the proteolysis reaction due to the emergence of protease enzymes by bacteria. Proteolysis is the reaction of protein hydrolysis to simpler compounds and over time can produce stinky base compounds [15]. Some examples of protease-producing bacteria commonly found in tofu are Streptococcus sp., Enterobacter sp., and Pseudomonas sp. The protease enzyme will hydrolyze the protein into a polypeptide, and the polypeptide will be broken down by peptidase into an amino acid. The existence of free amino acids will be hydrolyzed into volatile base compounds commonly referred to as total volatile base (TVB) [15]. Examples of TVB that are often found are indole, skatole, mercaptan, $\mathrm{H}_{2} \mathrm{~S}$, and other amines [16]. Among these compounds, mercaptan and $\mathrm{H}_{2} \mathrm{~S}$ are weakly acidic. Indole and skatole are alkaline, while other amines are strong bases. This is what causes the increase of $\mathrm{pH}$ in tofu.

3) The Change of Protein Content: The effect of exposure time on changes in protein levels in tofu can be seen in Figure 5. After exposed with ozonated water, the results show a decrease in protein content at different exposure time. The longer the time, the less protein levels remained in the tofu. When in contact with proteins, ozone will oxidize proteins and certain types of amino acids such as tryptophan, tyrosine, and cysteine. As a result, the protein's physical properties will change, including the ability of molecules for folding and binding. Changes in these properties can lead to the occurrence of protein denaturation [17].

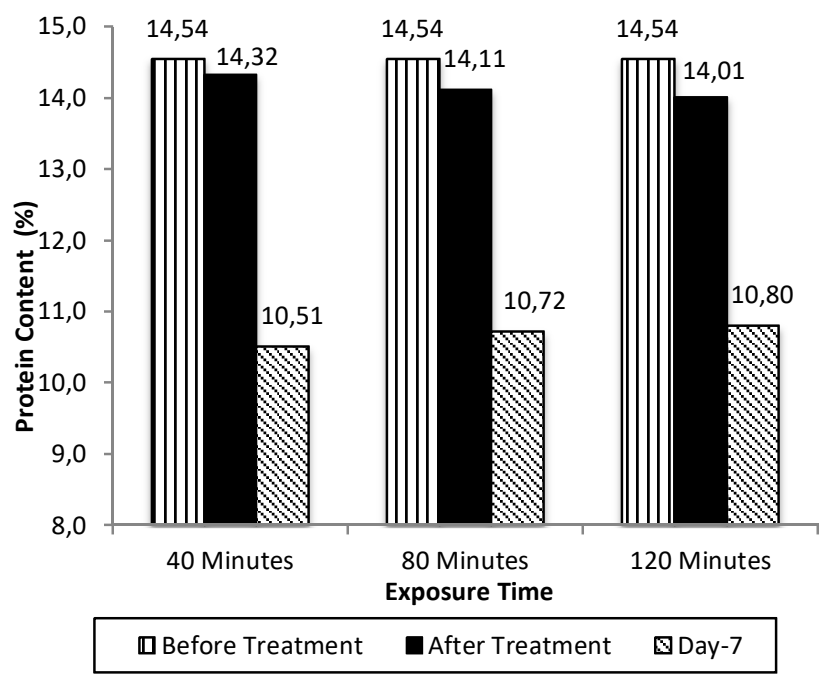

Fig. 5 Protein Content in Different Exposure Time (ozone dosage: 0.32 $\mathrm{mg} / \mathrm{L}$; storage temperature: $8^{\circ} \mathrm{C}$; water $\mathrm{pH}: 5$ )

Reduction in protein levels after contact with ozone can also be caused by ozone's ability to alter secondary and tertiary structures of proteins [18]. This is due to the ability of ozone to change the optical rotation of proteins. Changes in the value of specific optical rotations are caused by ozonolysis reactions to amino acid monomers in proteins. Changes will follow changes in protein structure in folding and binding, which can destroy the protein [17]. Also, protein damage due to ozone occurs in amino acid monomers in the protein, not amide bonds $\left(-\mathrm{CO}-\mathrm{NH}_{2}\right)$. Amide bonds in proteins are resistant to ozone attacks [17].

On day 7 , the results showed that samples with longer contact durations had higher protein levels although the difference was not significant. The reduction of protein on day 7 is caused by the microbial activity found in the tofu. Due to the less amount of TMAB in the tofu with 120 minutes exposure time, the rate of protein degradation is slower than that of 80 and 40 minutes. Reference [19] showed that the growth of microorganisms would cause rapid protein decomposition. Protein in the food during storage would decrease due to enzyme activity [10]. The proteins are degraded from complex molecules into simple molecules such as amino acids, ammonia, in which are volatile and are also referred to as TVB.

\section{B. The Effect of Replacement Period}

Tofu was exposed with ozonated water for 120 minutes, and the replacement was done every 40 and 60 minutes. Sample without water replacement was also observed in this study.

1) The Change of TMAB: The change of TMAB in different replacement period is shown in Figure 6. The results show that the more frequent the period of water replacement, the less the amount of TMAB contained in the tofu. This is because there is more ozone contacted with tofu in the more frequent replacements.

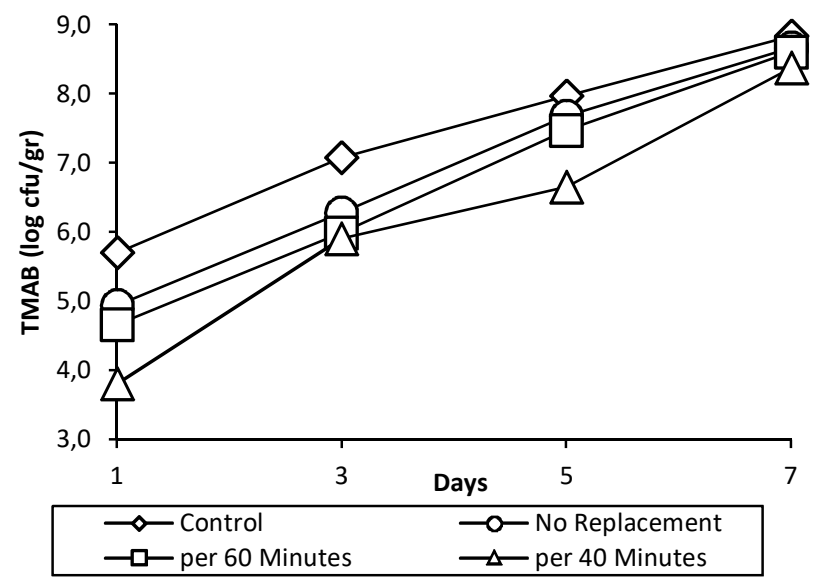

Fig. 6 TMAB In Different Replacement Period (ozone dosage: $0.32 \mathrm{mg} / \mathrm{L}$; storage temperature: $8^{\circ} \mathrm{C}$; water $\mathrm{pH}: 5$ )

If the ozonated water that contacts the tofu is renewed with the freshly produced one within a period of time, the amount of dissolved ozone that should be reduced will continue to be replaced with other dissolved ozone. Therefore, replacing every 40 minutes has the highest number of contacted ozone than replacement per 60 minutes and no replacement. It can also be interpreted that the more frequent the replacement of water, the more ozone is also able to disinfect bacteria in tofu. The renewal of ozonated water will replace ozone that has reacted and decomposed. 
Figure 6 also shows that the samples whose water is replaced more often have a lower increase of TMAB in day 7. It is caused by the decreased number of initial bacteria in the tofu after disinfection with ozonated water. The percentage of disinfection for each replacement period can be seen in Figure 7. Figure 7 shows that samples with replacement every 40 minutes had the highest percentage of disinfection compared with 60-minute replacements and those that were not replaced. It was able to disinfect bacteria by $96 \%$ (5.24 log cfu / gr). If the ozonated water is renewed within a period of time, the decomposed ozone will continue to be replaced with new dissolved ozone. Therefore, the water replacement every 40 minutes has the most amount of ozone compared to the 60 -minute period and that is not replaced at all.

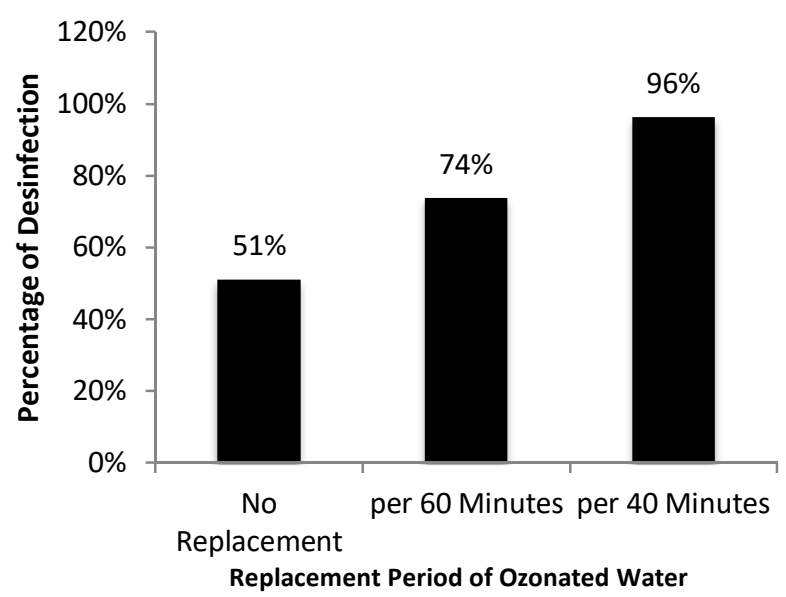

Fig. 7 Percentage of Disinfection in Different Replacement Period (ozone dosage: $0.32 \mathrm{mg} / \mathrm{L}$; storage temperature: $8^{\circ} \mathrm{C}$; water $\mathrm{pH}: 5$ )

2) The Change of $p H$ : The effect of the replacement period of the ozonated water on the $\mathrm{pH}$ change of tofu can be seen in Figure 8. The results show that the more frequent the water replacement period, the slower the increase of the $\mathrm{pH}$. On the $7^{\text {th }}$ day the lowest $\mathrm{pH}$ was found in the sample with replacement every 40 minutes, which was 6.58 . Whereas the $\mathrm{pH}$ value of tofu for replacement every 60 minutes and without replacement is 6.72 and 6.79 . The difference in $\mathrm{pH}$ that is not too significant is still categorized as accurate because the $\mathrm{pH}$ values in all samples are above the error margin of the $\mathrm{pH}$ meter, which is $\pm 0.02 \mathrm{pH}$ units.

The more frequent the replacement of ozonated water, the more the amount of ozone dissolved in water that can disinfect bacteria in the tofu. In the sample with replacement every 40 minutes, the number of TBMA living in it is the least compared to other samples. If the number of TBMA is less, the protease enzyme produced is also less. The number of protease enzymes that are less will have an impact on the less amount of protein degraded by TBMA through proteolysis reaction. As a result, the number of base compounds (TVB) produced also decreases, so the change in $\mathrm{pH}$ of the tofu is not too drastic.

Although the proteolysis reaction can occur without the presence of bacteria, the reaction has a slow rate due to the absence of compounds that can reduce the activation energy and accelerate the reaction rate. The presence of protease enzymes from bacteria will accelerate the rate of proteolysis reactions and, therefore, speed up tofu's damage. In other words, the replacement of ozonated water is effective in slowing the rate of increase in $\mathrm{pH}$ due to its ability to disinfect bacteria.

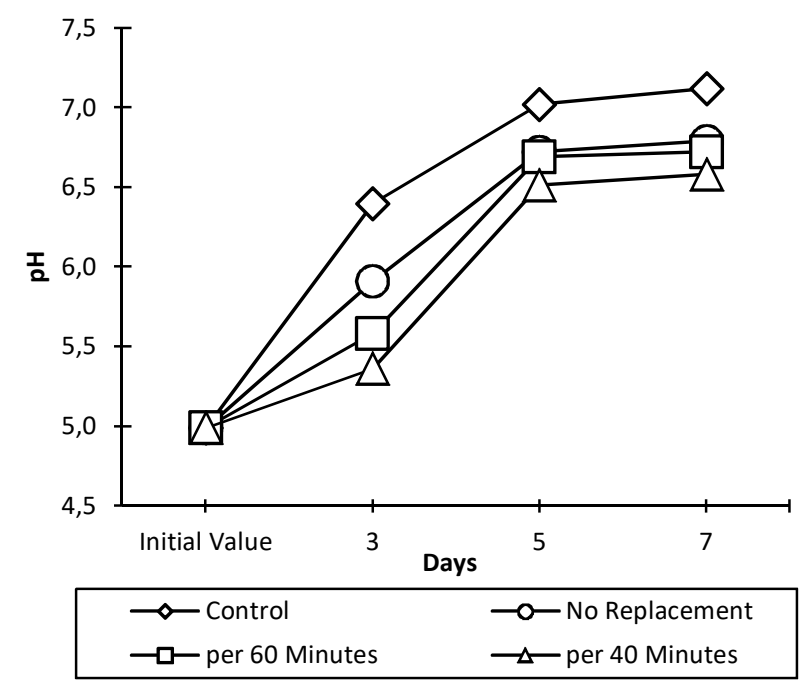

Fig. 8 pH of Tofu in Different Replacement Period (ozone dosage: 0.32 $\mathrm{mg} / \mathrm{L}$; storage temperature: $8^{\circ} \mathrm{C}$; water $\mathrm{pH}: 5$ )

3) The Change of Protein Content: The effect of the replacement period of ozonated water on changes in protein content can be seen in Figure 9. It can be observed that there is a substantial decrease in protein content after contacted with ozone. A more frequent replacement period will increase the amount of ozone contacted with tofu, thus providing more ozone doses to oxidize proteins. The more frequent the replacements will increase the amount of ozone dissolved in water, thus giving more ozone doses to oxidize proteins. As previously explained, ozone will degrade protein by reacting with the amino acid monomers in it. Damage to these amino acids can change the physical properties of proteins that have an impact on protein degradation [20].

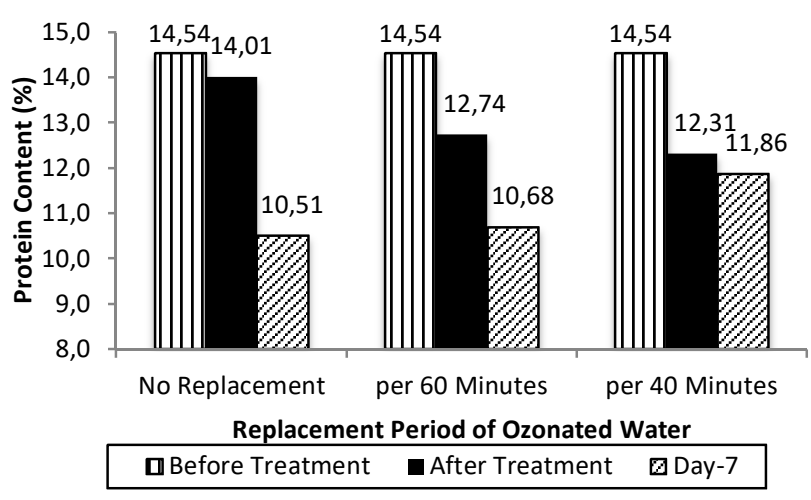

Fig. 9 Protein Content of Tofu on Different Replacement Period

On the other hand, there is a significant difference shown on protein levels at day 7. Although the protein content in the sample with replacement every 40 minutes decreases the most after being contacted with ozone, its protein content on day 7 has the highest value. The reduction of protein during storage is no longer affected by ozone but by the activity of microorganisms in the tofu. Tofu with fewer amounts of 
TMAB has a lower rate of protein decrease. This is because the fewer protease enzymes exist in the tofu, so the rate of protein hydrolysis will be slower.

\section{CONCLUSION}

To conclude, this research shows that the longer the exposure time between tofu and ozonated water $(0.32 \mathrm{mg} / \mathrm{L})$, the more preserved the tofu's quality. The exposure time of 120 minutes can disinfect TMAB for 51\%. Also, the replacement of ozonated water was effective to protect tofu's quality. The more frequent the replacement, the more preserved the quality of tofu. Replacement of ozonated water every 40 minutes can disinfect TMAB for $96 \%$ and therefore perform better to support the quality of tofu.

\section{ACKNOWLEDGMENT}

We are grateful for the Department of Chemical Engineering Universitas Indonesia's support by providing Intensification Process Laboratory. This research was also supported by Hibah PUTI Q1Q2, with series number NKB0296/UN2.R3.1/HKP.05.00/2019.

\section{REFERENCES}

[1] M. A. A. Mamun, M. A. Rahman, M. K. Zaman, Z. Ferdousi and M. A. Reza, "Toxicological effect of formalin as food preservative on kidney and liver tissues in mice model," IOSR Journal of Environmental Science, Toxicology and Food Technology, Volume 8, Issue 9 Ver. II, pp. 47-5, Sep. 2014.

[2] B. Maherani, M. Harich, S. Salmieri, and M. Lacroix, "Antibacterial Properties Of Combined non-thermal treatments based on bioactive edible coating, ozonation, and gamma irradiation on ready-to-eat frozen green peppers: evaluation of their freshness and sensory qualities," European Food Research and Technology, vol. 245, pp. 1095-1111, 2019.

[3] E.F. Karamah, S Z Adi, and N. Wajdi, "Effect of ozone exposure time and ozonated water replacement to control the quality of chicken meat," Journal of Physics: Conference Series, Vol. 1295 no. 012068, 2019.

[4] A.J. Brodowska, A. Nowak, and K. Śmigielski, "Ozone in the food industry: Principles of ozone treatment, mechanisms of action, and applications: An overview," Critical reviews in food science and nutrition, pp.1-26, 2017.

[5] E.F. Karamah, A.P. Ilmiyah, and N. Ismaningtyas, "The application of ozonated water to maintain the quality of tuna meat: the effect of contact time, contact temperature and ozone dosage". IOP Conf. Ser.: Mater. Sci. Eng. Vol, 509, no. 012004, 2019.

[6] A. Alexopoulos, S. Plessas, Y. Kourkoutas, C. Stefanis, S. Vavias, and C. Voidarou, "Experimental effect of ozone upon the microbial flora of commercially produced dairy fermented products," International Journal of Food Microbiology, vol. 246, pp. 5-11, 2017.

[7] R. Aslam, M.S. Alam, and P.A. Saeed, "Sanitization Potential of Ozone and Its Role in Postharvest Quality Management of Fruits and Vegetables," Food Engineering Reviews, vol. 12, pp. 48-67, 2020.

[8] S.J. e Granella, D. Christ, I. Werncke, T.R. Bechlin and S.R.M. Coelho, "Effect of drying and ozonation process on naturally contaminated wheat seeds," Journal of Cereal Science, vol. 80, pp. 205-211, 2018.

[9] S.T. Moraglio, L. Bosco, C. Pogolotti, L. Tavella, "Effect of ozone gas against life stages of Ephestia kuehniella Zeller (Lepidoptera: Pyralidae) in laboratory and a storehouse," Journal of Stored Products Research, vol. 79, pp. 132-138, 2018.

[10] M. Aponte, A. Anastasio, R. Marrone, R. Mercogliano, M.F. Peruzy, N. Murru, "Impact of gaseous ozone coupled to passive refrigeration system to maximize shelf-life and quality of four different fresh fish products," Food Science and Technology, vol. 93, pp. 412-419, 2018.

[11] Z. Zhou, S. Zuber, F. Cantergiani, I. Sampers, F. Devlieghere, and M. Uyttendaele, "Inactivation of Foodborne Pathogens and Their Surrogates on Fresh and Frozen Strawberries Using Gaseous Ozone," Frontiers in Sustainable Food Systems, vol. 2, p.51, 2018.

[12] B. Gim'enez, N. Graiver, L. Giannuzzi, and N. Zaritzky, "Treatment of beef with gaseous ozone: Physicochemical aspects and antimicrobial effects on heterotrophic microflora and listeria monocytogenes," Food Control, vol. 121, no. 107602, pp. 1-9, 2021.

[13] A. Baggio, · M. Marino, · N. Innocente, · M. Celotto, · and M. Maifreni, "Anti-microbial effect of oxidative technologies in food processing: an overview," European Food Research and Technology, vol. 246, pp. 669-692, 2020.

[14] E.F. Karamah, R.R. Najeges, M.Z. Zahirsyah, "The influence of ozone dosage, exposure time and contact temperature of ozone in controlling food quality (case study: tofu)," IOP Conf. Series: Materials Science and Engineering, vol. 509, no. 012117, 2019.

[15] O'Donnell, C., Tiwari, B.K., Cullen, P.J. and Rice, R.G. eds., (2012). Ozone in food processing. John Wiley \& Sons.

[16] Kleiner, I.S. dan J.M. Orten. (1975). Biochemistry. New York: The C.V. Mosby Co.

[17] A. Baggio, M. Marino, N. Innocente, M. Celotto, and M. Maifreni, "Anti-microbial effect of oxidative technologies in food processing: an overview," European Food Research and Technology, vol. 246, pp. 669-692, 2020.

[18] E.F. Karamah, N. Ismaningtyas, and A.P. Ilmiyah. "The effect of exposure time and water replacement in the application of ozonated water to maintain the quality of tuna". IOP Conf. Ser.: Mater. Sci. Eng. Vol, 509, no. 012092, 2019.

[19] S. Shezi, L.S. Magwaza, A. Mditshwa, and S.Z. Tesfay," Review. Changes in biochemistry of fresh produce in response to ozone postharvest treatment," Scientia Horticulturae, vol. 269, pp.1-9, 2020 .

[20] E.F. Karamah, N. Ismaningtyas, and A.P. Ilmiyah. "The effect of exposure time and water replacement in the application of ozonated water to maintain the quality of tuna”. IOP Conf. Ser.: Mater. Sci. Eng. Vol, 509, no. 012092, 2019. 